\title{
$\mathrm{J}$

\section{Inhibition of [FeFe]-Hydrogenases by Formaldehyde and Wider Mechanistic Implications for Biohydrogen Activation}

\author{
Carina E. Foster, ${ }^{\dagger}$ Tobias Krämer, ${ }^{\dagger}$ Annemarie F. Wait, ${ }^{\dagger}$ Alison Parkin, ${ }^{\dagger}$ David P. Jennings, ${ }^{\dagger}$ \\ Thomas Happe, ${ }^{\ddagger}$ John E. McGrady, ${ }^{*}{ }^{\dagger}$ and Fraser A. Armstrong $*^{\dagger}$ \\ ${ }^{\dagger}$ Department of Chemistry, Inorganic Chemistry Laboratory, University of Oxford, South Parks Road, Oxford, OX1 3QR, United \\ Kingdom \\ ${ }^{\ddagger}$ Ruhr-Universität, Lehrstuhl fur Biochemie der Pflanzen, AG Photobiotechnologie, 44780 Bochum, Germany
}

\section{Supporting Information}

ABSTRACT: Formaldehyde-a rapid and reversible inhibitor of hydrogen evolution by [FeFe]-hydrogenases-binds with a strong potential dependence that is almost complementary to that of $\mathrm{CO}$. Whereas exogenous $\mathrm{CO}$ binds tightly to the oxidized state known as $\mathrm{H}_{\mathrm{ox}}$ but very weakly to a state two electrons more reduced, formaldehyde interacts most strongly with the latter. Formaldehyde thus intercepts increasingly reduced states of the catalytic cycle, and density functional theory calculations support the proposal that it reacts with the $\mathrm{H}$-cluster directly, most likely targeting an otherwise elusive and highly reactive Fe-hydrido $(\mathrm{Fe}-\mathrm{H})$ intermediate.

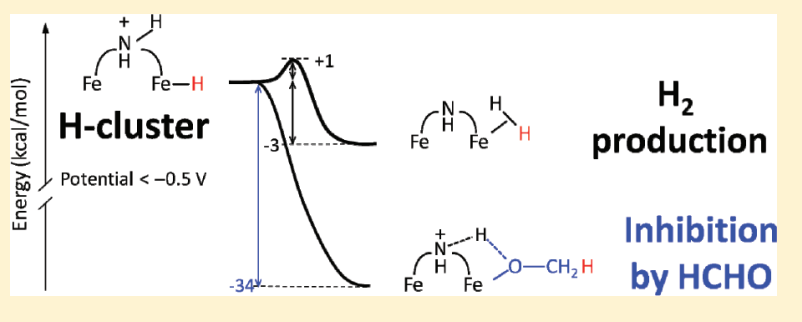

\section{INTRODUCTION}

Microbial metalloenzymes known as hydrogenases attract great interest due to their potential for developing fermentative or photosynthetic "biohydrogen" production and as inspiration for catalysts in fuel cells and artificial photosynthesis. ${ }^{1-3}$ Protein film electrochemistry (PFE) studies have established that hydrogenases catalyze $\mathrm{H}_{2}$ oxidation and $\mathrm{H}_{2}$ production with minimal driving force (overpotential requirement) comparable to the facile $2 \mathrm{H}^{+} / \mathrm{H}_{2}$ interconversion on platinum. ${ }^{4}$ The two main classes are known as $[\mathrm{FeFe}]$ - and [ $\mathrm{NiFe}]$-hydrogenases. The $[\mathrm{FeFe}]$-hydrogenases, which are most active in $\mathrm{H}_{2}$ production, contain a unique active site known as the " $\mathrm{H}$ cluster", which is shown in Figure 1.

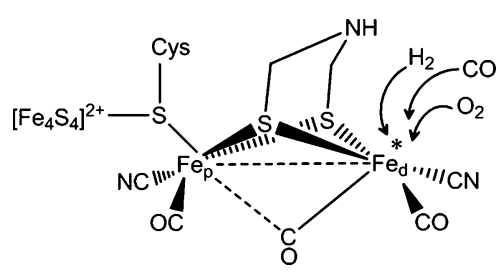

Figure 1. Active site (H-cluster) of an $[\mathrm{FeFe}]$-hydrogenase. The exchangeable binding site at the distal iron $\left(\mathrm{Fe}_{\mathrm{d}}\right)$ is marked by an asterisk.

The structure of the $\mathrm{H}$-cluster has been determined by crystallography and spectroscopy. The six Fe atoms form two domains, a [4Fe-4S] cluster domain and a binuclear domain $\left(2 \mathrm{Fe}_{\mathrm{H}}\right)$ linked by a single cysteine sulfur ligand. ${ }^{5}$ The individual $\mathrm{Fe}$ atoms in $2 \mathrm{Fe}_{\mathrm{H}}$, designated proximal $\left(\mathrm{Fe}_{\mathrm{p}}\right)$ and distal $\left(\mathrm{Fe}_{\mathrm{d}}\right)$ relative to the $[4 \mathrm{Fe}-4 \mathrm{~S}]$ domain, are connected by a bridging dithiolmethylamine ligand. ${ }^{6,7}$ In the oxidized state $\mathrm{H}_{\mathrm{ox}}$ as determined from the structure of the hydrogenase I enzyme from Clostridium pasteurianum $(C p \mathrm{I}), \mathrm{Fe}_{\mathrm{p}}$ is coordinated by one $\mathrm{CO}$ and one $\mathrm{CN}^{-}$ligand and shares a bridging $\mathrm{CO}$ with $\mathrm{Fe}_{\mathrm{d}}{ }^{6}$ The distal $\mathrm{Fe}$ is also coordinated by one $\mathrm{CO}$ and one $\mathrm{CN}^{-}$ ligand, and an additional binding site is vacant or occupied by an exchangeable O-ligand, either a hydroxide or a water molecule. ${ }^{8}$ In the structure of the $[\mathrm{FeFe}]$-hydrogenase from Desulfovibrio desulfuricans (DdHydAB), which was crystallized in the $\mathrm{H}_{\text {red }}$ form, the bridging $\mathrm{CO}$ moves to a terminal position on $\mathrm{Fe}_{\mathrm{d}} \cdot{ }^{9}$ Spectroscopic studies favor an oxidation state assignment of $[4 \mathrm{Fe}-4 \mathrm{~S}]^{2+} \mathrm{Fe}_{\mathrm{p}}(\mathrm{I}) \mathrm{Fe}_{\mathrm{d}}$ (II) for $\mathrm{H}_{\mathrm{ox}}$, whereas the EPR-silent $\mathrm{H}_{\text {red }}$ state is assigned as $[4 \mathrm{Fe}-4 \mathrm{~S}]^{2+} \mathrm{Fe}(\mathrm{I}) \mathrm{Fe}(\mathrm{I})$ or the hydrido species $[4 \mathrm{Fe} 4 \mathrm{~S}]^{2+} \mathrm{Fe}(\mathrm{II}) \mathrm{Fe}(\mathrm{II}) \mathrm{H}^{-}$. A two-electron "super-reduced" state symbolized as $\mathrm{H}_{\text {sred }}$ remains poorly characterized-not surprising, since such a species should be highly reactive, rapidly evolving $\mathrm{H}_{2}$ and escaping detection. ${ }^{5,10}$ Despite the importance for understanding how $\mathrm{H}_{2}$ is produced so efficiently, mechanistic detail from experiments is lacking, mainly due to the difficulty of identifying transient, strongly reducing intermediates in a very rapid catalytic cycle (turnover frequency $\gg 1000 \mathrm{~s}^{-1}$ ) involving a sole ubiquitous substrate $\left(\mathrm{H}_{\mathrm{aq}}^{+}\right)$.

An important (and now established) mechanistic clue stemmed from infrared spectroscopy and X-ray crystallography, which showed that $\mathrm{CO}$, a competitive inhibitor of $\mathrm{H}_{2}$ oxidation, ${ }^{11}$ binds to the vacant/exchangeable binding site of $\mathrm{Fe}_{\mathrm{d}}$ in $\mathrm{H}_{\mathrm{ox}}$ thereby locating $\mathrm{Fe}_{\mathrm{d}}$ as the site of $\mathrm{H}_{2}$ binding, most likely in a side-on manner. ${ }^{12-14}$ Carbon monoxide was shown

Received: March 2, 2012

Published: April 18, 2012 
to protect against the fatal inhibitor $\mathrm{O}_{2}$, also thought to bind at $\mathrm{Fe}_{\mathrm{d}}{ }^{15}$

A second opportunity for gaining fresh mechanistic insight is provided by our recent discovery, through PFE studies, that formaldehyde ( $\mathrm{HCHO})$ is a rapid and reversible inhibitor of [FeFe]-hydrogenases. ${ }^{16}$ A unique feature of PFE is its ability to measure catalytic activity (directly as current) as a continuous function of electrode potential: it can therefore identify potential boundaries between intermediates differing in oxidation level but remaining at steady state during the catalytic cycle. As an example, consider a potential sweep experiment initiated at an electrode potential where $\mathrm{H}_{\mathrm{ox}}$ is dominant: as the potential is lowered, increasingly reduced states populate the catalytic cycle, and it is appropriate to distinguish these steady-state redox levels generally as $\mathrm{H}_{\text {ox- }-1}$, $\mathrm{H}_{\text {ox-2 }}$, etc., rather than using spectroscopic labels such as $\mathrm{H}_{\text {red. }}$. Each of these catalytic oxidation levels includes different protonation states, and by adopting this nomenclature, we are able to focus on the number of electrons transferred to catalytic intermediates $(0,1,2)$ rather than where the electrons (and protons) are localized.

In the absence of unlikely long-range conformational changes, inhibitors should discriminate between different oxidation levels according to how intimately they interact with the active site metals. To help identify the target for $\mathrm{HCHO}$ attack, we have therefore made a detailed comparison between the potential dependences of inhibition by $\mathrm{HCHO}$ and $\mathrm{CO}$. We focused on the $[\mathrm{FeFe}]$-hydrogenase $(\mathrm{CaHydA})$ from Clostridium acetobutylicum because it does not rapidly form an anaerobic oxidized inactive state that complicates the quantitative analysis at high potential. Two other [FeFe]hydrogenases, $D d \mathrm{HydAB}$ (from $D$. desulfuricans) and $\mathrm{CrHydA} 1$ (from Chlamydomonas reinhardtii), were studied in less detail, for this reason. Density functional theory (DFT) has been used to explore the associated potential energy surface.

\section{RESULTS AND DISCUSSION}

Figure 2 shows catalytic cyclic voltammograms for $\mathrm{CaHydA}$ at $\mathrm{pH} 6$ in the presence of $\mathrm{H}_{2}$. At high potential, the positive current is due to $\mathrm{H}_{2}$ oxidation, whereas as the potential is lowered, $\mathrm{H}^{+}$reduction occurs. The negative $\mathrm{H}^{+}$reduction current shows a variably steep slope, attributable to the very high activity of the $\mathrm{H}$-cluster, which renders interfacial electron transfer the rate-limiting step. ${ }^{17}$ As shown in Figure $2 \mathrm{~A}$, the $\mathrm{H}_{2}$ oxidation activity of $\mathrm{CaHydA}$ is inhibited by $\mathrm{CO}$ to a greater extent than $\mathrm{H}^{+}$reduction; at $-0.8 \mathrm{~V},>80 \%$ of the current measured in the absence of $\mathrm{CO}\left(80 \% \mathrm{H}_{2}\right.$ in $\left.\mathrm{N}_{2}\right)$ persists in the presence of $0.6 \% \mathrm{CO}(8.1 \mu \mathrm{M} \mathrm{CO})$. In comparison, at $0 \mathrm{~V}$, $<40 \%$ of the activity is sustained in the presence of the inhibitor. In these experiments, the $\mathrm{CO}$ flows continuously through the cell headspace-its percentage level controlled by mass-flow controllers.

The decrease in $\mathrm{CO}$ inhibition at highly reducing potentials is observed as a sharp increase in current at $-0.6 \mathrm{~V}$, the rationale being that at very negative potentials, the enzyme rapidly releases $\mathrm{CO}$, regenerating catalytically active enzyme. The voltammogram does not retrace as the electrode potential is raised to more positive values: instead, hysteresis is observed due to the slow rate at which CO rebinds. ${ }^{11}$ The $20 \%$ decrease in current observed at $-0.8 \mathrm{~V}$ relative to the $\mathrm{CO}$-free experiment reflects the irreversible breakdown of the unstable $\mathrm{H}_{\text {ox }-1}-\mathrm{CO}$ state $^{11,18}$ formed above $-0.6 \mathrm{~V}$. Analogous behavior
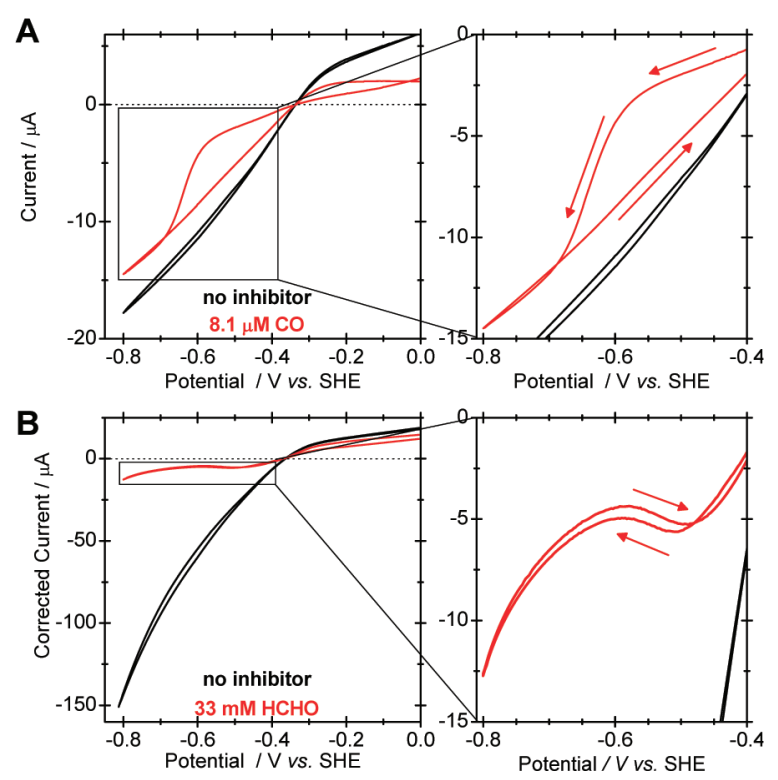

Figure 2. Cyclic voltammograms showing the complementary effects of $\mathrm{CO}$ and $\mathrm{HCHO}$ on $\mathrm{CaHydA}$. All scans were started from the highpotential limit. Black traces were recorded before the addition of inhibitor, and red scans were performed in the presence of (A) $0.6 \%$ $\mathrm{CO}(8.1 \mu \mathrm{M}), 80 \% \mathrm{H}_{2}$, and $20 \%\left(\mathrm{~N}_{2}+\mathrm{CO}\right)$ or (B) $33 \mathrm{mM} \mathrm{HCHO}$ and $100 \% \mathrm{H}_{2}$. "Corrected current" denotes that data have been corrected for a linear loss of current over time (see the Supporting Information). Conditions: $\mathrm{pH} 6$ phosphate, $3000 \mathrm{rpm}, 3 \mathrm{mVs}^{-1}$, dark, $5{ }^{\circ} \mathrm{C}(\mathrm{A})$, and $20{ }^{\circ} \mathrm{C}(\mathrm{B})$. The right-hand panels show expanded sections of each voltammogram.

is observed for $\mathrm{D} d \mathrm{HydAB}$ and $\mathrm{CrHydAl}$ (Figure $\mathrm{S} 3$ in the Supporting Information).

Figure $2 \mathrm{~B}$ shows that in contrast to $\mathrm{CO}, \mathrm{HCHO}$ inhibits $\mathrm{H}^{+}$ reduction activity more than $\mathrm{H}_{2}$ oxidation. For $\mathrm{CaHydA}$, a total concentration of $33 \mathrm{mM} \mathrm{HCHO}$ (corresponding to approximately $15 \mu \mathrm{M}$ anhydride) results in the loss of approximately $90 \%$ of the $\mathrm{H}^{+}$reduction current at $-0.8 \mathrm{~V}$, whereas $70 \%$ of the $\mathrm{H}_{2}$ oxidation activity remains at $0 \mathrm{~V}$. Importantly, the voltammogram obtained in the presence of $\mathrm{HCHO}$ reveals a sharp transition between -0.5 and $-0.6 \mathrm{~V}$, superimposed on the general slope mentioned above. By replacing the buffer solution with one that is free of formaldehyde (an important feature of the PFE experiment), the uninhibited voltammetry is restored.

Figure 3 shows the results of chronoamperometry experiments to measure the extent of inhibition of $\mathrm{CaHydA}$ activity as a function of electrode potential for both $\mathrm{CO}$ and $\mathrm{HCHO}$. Attempts to fit the data to a single Nernstian sigmoid resulted in $n$ values $<0.5$, which is clearly unrealistic; much better fits were achieved using two sequential $n=1$ sigmoids that divide the data into three regions differing by one electron (details are given in the Supporting Information). For CO binding, the results are fully consistent with the voltammetry and may be discussed in the context of the results published by ourselves ${ }^{11}$ and by Baffert et al. ${ }^{18}$ The common conclusion of those papers was that whereas $\mathrm{CO}$ binds strongly to $\mathrm{H}_{\mathrm{ox}}$, it binds less tightly to the state $\mathrm{H}_{\text {red }}$ and results in irreversible damage to the $\mathrm{H}$ cluster in that state. Baffert et al. also noted that $\mathrm{CO}$ is easily released at low potential, and the data in Figures 2 and 3 indeed show that $\mathrm{CO}$ has very little affinity for the enzyme in the $\mathrm{H}_{\mathrm{ox}-2}$ level. The $\mathrm{CO}$ binding profile can now be used to interpret the behavior of $\mathrm{CaHydA}$ with $\mathrm{HCHO}$ : there are three potential 


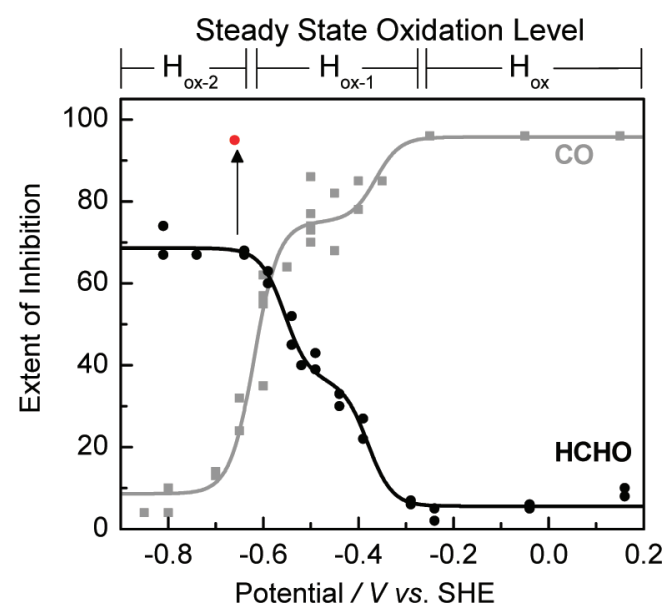

Figure 3. Plot showing the potential dependence of the extent of $\mathrm{CO}$ and $\mathrm{HCHO}$ inhibition of $\mathrm{CaHydA}$. The extent of inhibition was measured after $100 \mathrm{~s}$ of exposure to either $10 \% \mathrm{CO}(107 \mu \mathrm{M}$ in $80 \%$ $\mathrm{H}_{2} / 20 \%\left(\mathrm{~N}_{2}+\mathrm{CO}\right)$ (gray squares) or $4.5 \mathrm{mM} \mathrm{HCHO}$ in $100 \% \mathrm{H}_{2}$ (black circles). The data were fitted to two $n=1$ nernstian sigmoids using Microsoft Excel Solver. Conditions: pH 6 phosphate, 2500 rpm, $20{ }^{\circ} \mathrm{C}$, and dark. An additional datum point (red circle) for $\mathrm{HCHO}$ is shown recorded under identical conditions with the exception of $\mathrm{HCHO}$ concentration, which was increased to $45 \mathrm{mM}$, showing that under these conditions, $95 \%$ of $\mathrm{H}_{2}$ production activity is inhibited at $-0.6 \mathrm{~V}$. domains, with reactivities toward $\mathrm{HCHO}$ lying in the order $\mathrm{H}_{\mathrm{ox}-2}>\mathrm{H}_{\mathrm{ox}-1}>\mathrm{H}_{\mathrm{ox}}$, that is, the opposite trend to $\mathrm{CO}$ binding. The behavior is consistent with previous work showing that in the presence of $\mathrm{HCHO}, \mathrm{H}_{2}$ production is more inhibited than $\mathrm{H}_{2}$ oxidation, ${ }^{16}$ but much more detail is now provided, notably the close coincidence between the potential for rapid $\mathrm{CO}$ release and the intensification of $\mathrm{HCHO}$ inhibition. Similar complementarity between $\mathrm{CO}$ and $\mathrm{HCHO}$ in the inhibition of $\mathrm{H}^{+}$reduction was observed for the other hydrogenases (voltammograms for $\mathrm{D} d \mathrm{Hyd} \mathrm{AB}$ and $\mathrm{CrHydAl}$ and chronoamperometric data for $\mathrm{CrHydAl}$ are shown in Figures S3, S4, and S6 in the Supporting Information). However, it was difficult to analyze the data in the $\mathrm{H}_{2}$ oxidation region for these enzymes because they undergo a greater degree of anaerobic inactivation.

The strong potential dependence of the inhibition of $\mathrm{H}^{+}$ reduction by $\mathrm{HCHO}$, observed with three different $[\mathrm{FeFe}]$ hydrogenases, and the complementary behaviors of $\mathrm{CO}$ and $\mathrm{HCHO}$ are compelling evidence that $\mathrm{HCHO}$ reacts directly at the $\mathrm{H}$-cluster. Indeed, $\mathrm{HCHO}$ affords partial protection against inhibition by $\mathrm{CO},{ }^{16}$ and further experiments showed that it also offers partial protection against inactivation by $\mathrm{O}_{2}$ (Supporting Information, Figure S7).

To explore the nature of the interactions between the $\mathrm{H}$ cluster and $\mathrm{HCHO}$, we used DFT to calculate the potential energy surfaces. In particular, we sought to establish how $\mathrm{HCHO}$ might intercept intermediates in $\mathrm{H}_{2}$ evolution

Scheme 1. How Formaldehyde May Intercept Intermediates in the Catalytic Cycle of [FeFe]-Hydrogenases, According to Their Oxidation Level $^{a}$
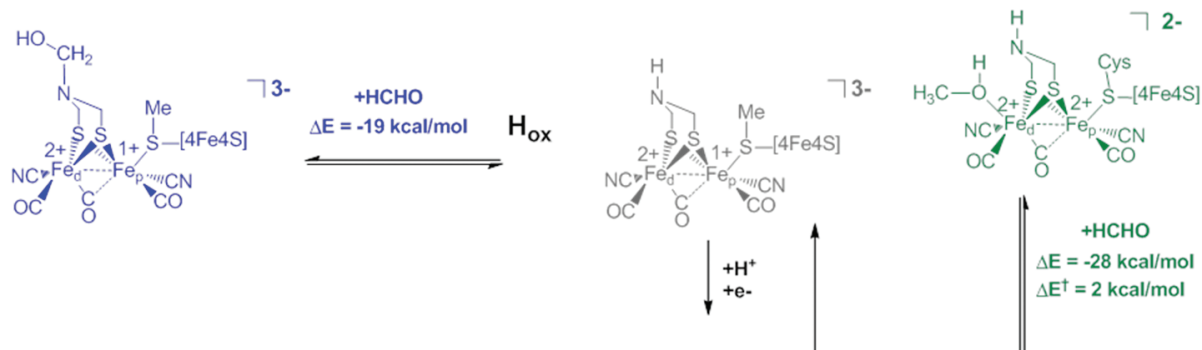

Hydride reduction of $\mathrm{HCHO}$

$$
O C \mathrm{OC}
$$
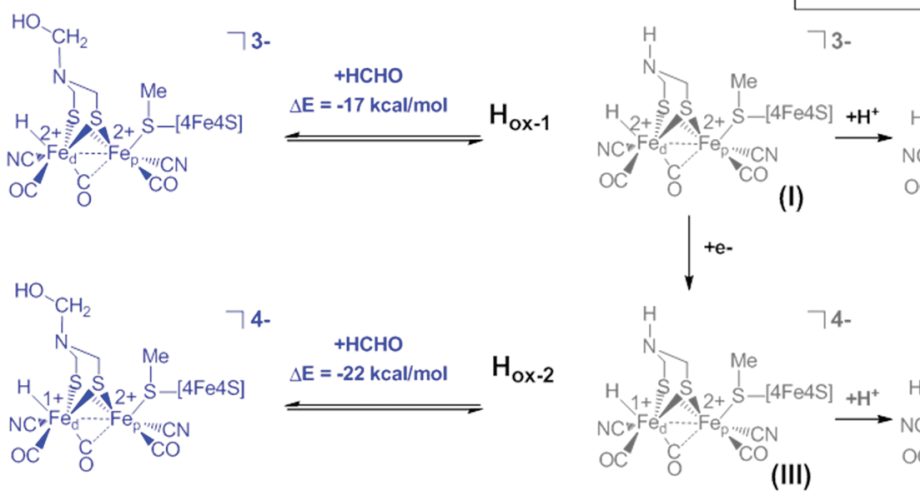

(III)

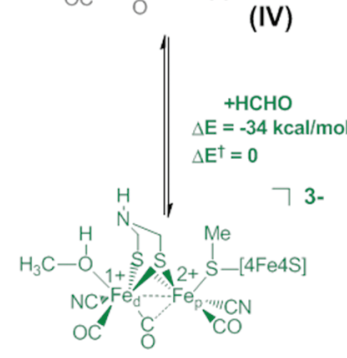

Hydride reduction of $\mathrm{HCHO}$

Schiff-base chemistry

${ }^{a}$ Formaldehyde products are shown in green (hydride attack) and blue (Schiff base attack). Species in gray are intermediates proposed on the basis of DFT calculations by de Gioia and colleagues (ref 19e). 
corresponding to oxidation levels $\mathrm{H}_{\mathrm{ox}-1}$ and $\mathrm{H}_{\mathrm{ox}-2}$. Proton reduction by [FeFe]-hydrogenases has been studied extensively by DFT, ${ }^{19-24}$ most recently by de Gioia and co-workers, ${ }^{19}$ who incorporated the $[4 \mathrm{Fe}-4 \mathrm{~S}]$ cluster domain into their model. We followed the computational methodology developed in ref 19e, and full details are given in the Supporting Information. The pathways for $\mathrm{H}_{2}$ evolution by both $\mathrm{H}_{\mathrm{ox}-1}$ and $\mathrm{H}_{\mathrm{ox}-2}$ are shown in Scheme 1 in gray-where the structures of the various intermediates are essentially identical to those reported by de Gioia and co-workers. At this level of theory, the formation of $\mathrm{H}_{2}$ from the intermediate hydride $\mathrm{IV}\left(\mathrm{H}_{\mathrm{ox}-2}\right.$ level $)$ is exothermic $(-3 \mathrm{kcal} / \mathrm{mol})$, whereas the corresponding reaction from II $\left(\mathrm{H}_{\text {ox-1 }}\right.$ level$)$ is endothermic, $\Delta E=+4 \mathrm{kcal} / \mathrm{mol}$. The $7 \mathrm{kcal} /$ mol additional driving force at the $\mathrm{H}_{\text {ox-2 }}$ level relative to the $\mathrm{H}_{\text {ox-1 }}$ level is consistent with the anticipated higher electron density on the hydride (greater hydridicity). The established chemistry of aldehydes offers two distinct possibilities for interaction with the H-cluster: (1) nucleophilic attack at the carbonyl-C by a $\mathrm{Fe}_{\mathrm{d}}$ hydride species leading to methanol-like derivatives (analogous to borohydride reductions) and (2) Schiff base chemistry at the bridgehead-N.

Considering first the hydridic attack on $\mathrm{HCHO}$, at the $\mathrm{H}_{\mathrm{ox}-1}$ level, the formation of methanol, bound to $\mathrm{Fe}_{\mathrm{d}}$ via the oxygen atom, is strongly exothermic $(\Delta E=-28 \mathrm{kcal} / \mathrm{mol}$ relative to free reactants). The $\mathrm{H}_{\text {ox-1 }}$ level of the $\mathrm{H}$-cluster is therefore thermodynamically competent to bind $\mathrm{HCHO}$. The reaction coordinate features a rather asynchronous transition state only $+2 \mathrm{kcal} / \mathrm{mol}$ above the reactants where hydride transfer is well developed but the proton remains bound strongly to the bridgehead-N. Significantly, the reaction with $\mathrm{HCHO}$ is also $>30 \mathrm{kcal} / \mathrm{mol}$ more favorable than the proton reduction step at the same oxidation level. Upon adding a further electron to achieve the $\mathrm{H}_{\mathrm{ox}-2}$ level, the corresponding surface for $\mathrm{HCHO}$ binding appears to be barrierless: we have been unable to locate a transition state separating reactants from the methanol product. The overall reaction is again strongly exothermic $(\Delta E$ $=-34 \mathrm{kcal} / \mathrm{mol}$ ), and the difference of $6 \mathrm{kcal} / \mathrm{mol}$ between the $\mathrm{H}_{\text {ox-1 }}$ and the $\mathrm{H}_{\text {ox- } 2}$ states mirrors that noted for the competing proton reduction step $(\Delta \Delta E=7 \mathrm{kcal} / \mathrm{mol})$.

Schiff base chemistry with the bridgehead-N produces aminol intermediates $(\Delta E=-18,-17$, and $-22 \mathrm{kcal} / \mathrm{mol}$ for reactions at levels $\mathrm{H}_{\mathrm{ox}}, \mathrm{H}_{\mathrm{ox}-1}$, and $\mathrm{H}_{\mathrm{ox}-2}$, respectively). In the presence of protons, these would, in turn, decompose exothermically to form irreversible products via dehydrated imine intermediates, regardless of the oxidation level. We do not, however, consider these subsequent steps explicitly, as the energetics are dominated by the large and unphysical electrostatic components arising from the high negative charge on the isolated clusters.

Both Schiff base modification of the H-cluster and formation of a strongly bound methanol are consistent with the enhanced inhibition observed when $\mathrm{H}_{2}$ production is monitored at a more negative potential, but neither option is consistent with the observed reversibility of the inhibition. The protein environment around the H-cluster must therefore play an important role in destabilizing or hindering formation of the exothermic final products, thus moderating the actual potency of the aldehyde as an enzyme inhibitor. Unlike Schiff base chemistry, hydridic attack on $\mathrm{HCHO}$ does not result in strong covalent modification of the enzyme itself, leading us to favor the latter. Experiments designed to detect any release of methanol have so far been negative, consistent with reactivation (either by raising the potential or removing $\mathrm{HCHO}$ from the solution) being a straightforward reversal of the relevant steps of Scheme 1.

Hydridic reduction of $\mathrm{HCHO}$ by the $\mathrm{H}$-cluster, even if not completed to release a product, presents a striking parallel with the hydrogenation catalysts developed by Noyori. ${ }^{25,26}$ The essence of this analogy, depicted in Figure 4, is that in both

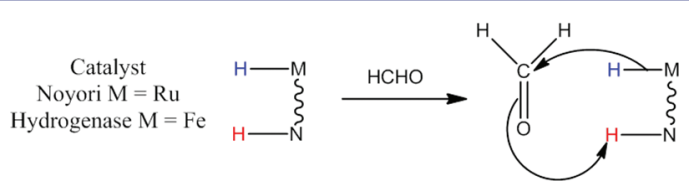

Figure 4. Cartoon showing the similarity between the proposed reaction of an $[\mathrm{FeFe}]$-hydrogenases with formaldehyde and the known reaction of the Noyori catalyst.

cases $\mathrm{HCHO}$ targets a state in which a reactive metal hydride is generated at an optimal position relative to an acidic amine. Nucleophilic attack by the hydride at the carbon with concomitant proton transfer to the oxygen leads to substrate reduction. Significantly, for the naked H-cluster, reaction with $\mathrm{HCHO}$ competes very favorably with catalytic formation of the $\mathrm{H}^{-}---\mathrm{H}^{+}$bond. If this mechanism is correct, it could open up interesting new possibilities for $[\mathrm{FeFe}]$-hydrogenases to be engineered to perform other reactions.

\section{ASSOCIATED CONTENT}

\section{S Supporting Information}

Full materials and methods, current correction used for Figure 3B (S1), details of methodology used to generate data for Figure 3 (S2), cyclic voltammograms of $\mathrm{DdHydAB}$ and $\mathrm{CrHydAl}$ in the presence of $\mathrm{HCHO}$ and $\mathrm{CO}$ (S3 and S4), derivation of the double nernstian sigmoid equation used to fit data in Figure 3, analogous Figure 3 data for CrHydAl (S6), chronoamperometry experiment showing partial protection against irreversible $\mathrm{O}_{2}$ damage by $\mathrm{HCHO}$ (S7), full details of DFT calculations, and optimized atomic coordinates for all relevant structures. This material is available free of charge via the Internet at http://pubs.acs.org.

\section{AUTHOR INFORMATION}

\section{Corresponding Author}

E-mail: fraser.armstrong@chem.ox.ac.uk; john.mcgrady@chem. ox.ac.uk

\section{Notes}

The authors declare no competing financial interest.

\section{ACKNOWLEDGMENTS}

This research was supported by the Biological and Biotechnological Sciences Research Council (Grant H003878-1), the Engineering and Physical Sciences Research Council (studentships to C.F. and A.W.), and the Deutsche Forschungsgemeinschaft (HA 2555/2-1). A.P. thanks Merton College for a Junior Research Fellowship. We thank Christine Cavazza and Juan Fontecilla-Camps for providing a sample of $\mathrm{Dd} \mathrm{HydAB}$.

\section{REFERENCES}

(1) Tard, C.; Pickett, C. J. Chem. Rev. 2009, 109, 2245.

(2) Gust, D.; Moore, T. A.; Moore, A. L. Acc. Chem. Res. 2009, 42, 1890.

(3) Gloaguen, F.; Rauchfuss, T. B. Chem. Soc. Rev. 2009, 38, 100. 
(4) Armstrong, F. A.; Belsey, N. A.; Cracknell, J. A.; Goldet, G.; Parkin, A.; Reisner, E.; Vincent, K. A.; Wait, A. F. Chem. Soc. Rev. 2009, $38,36$.

(5) Fontecilla-Camps, J. C.; Volbeda, A.; Cavazza, C.; Nicolet, Y. Chem. Rev. 2007, 107, 4273.

(6) Nicolet, Y.; Lemon, B. J.; Fontecilla-Camps, J. C.; Peters, J. W. Trends Biochem. Sci. 2000, 25, 138.

(7) Silakov, A.; Wenk, B.; Reijerse, E.; Lubitz, W. Phys. Chem. Chem. Phys. 2009, 11, 6592.

(8) Pandey, A. S.; Harris, T. V.; Giles, L. J.; Peters, J. W.; Szilagyi, R. K. J. Am. Chem. Soc. 2008, 130, 4533.

(9) Nicolet, Y.; Piras, C.; Legrand, P.; Hatchikian, C. E.; FontecillaCamps, J. C. Structure (London) 1999, 7, 13.

(10) Silakov, A.; Reijerse, E. J.; Albracht, S. P. J.; Hatchikian, E. C.; Lubitz, W. J. Am. Chem. Soc. 2007, 129, 11447.

(11) Goldet, G.; Brandmayr, C.; Stripp., S. T.; Happe, T.; Cavazza, C.; Fontecilla-Camps, J. C.; Armstrong, F. A. J. Am. Chem. Soc. 2009, 131, 14979.

(12) Roseboom, W.; Lacey, A. L.; Fernandez, V. M.; Hatchikian, E. C.; Albracht, S. P. J. J. Biol. Inorg. Chem. 2006, 11, 102.

(13) Lemon, B. J.; Peters, J. W. J. Am. Chem. Soc. 2000, 122, 3793.

(14) Lemon, B. J.; Peters, J. W. Biochemistry 1999, 38, 12969.

(15) Stripp, S. T.; Goldet, G.; Brandmayr, C.; Sanganas, O.; Vincent, K. A.; Haumann, M.; Armstrong, F. A.; Happe, T. Proc. Natl. Acad. Sci. U.S.A. 2009, 106, 17331.

(16) Wait, A. F.; Brandmayr, C.; Stripp, S. T.; Cavazza, C.; Fontecilla Camps, J. C.; Happe, T.; Armstrong, F. A. J. Am. Chem. Soc. 2011, 133, 1282.

(17) Léger, C.; Jones, A. K.; Albracht, S. P. J.; Armstrong, F. A. J. Phys. Chem. B 2002, 106, 13058.

(18) Baffert, C.; Bertini, L.; Lautier, T.; Greco, C.; Sybirna, K.; Ezanno, P.; Etienne, E.; Soucaille, P.; Bertrand, P.; Bottin, H.; MeynialSalles, I.; De Gioia, L.; Léger, C. J. Am. Chem. Soc. 2011, 133, 2096.

(19) (a) Bruschi, M.; Fantucci, P.; de Gioia, L. Inorg. Chem. 2002, 41, 1421. (b) Bruschi, M.; Fantucci, P.; de Gioia, L. Inorg. Chem. 2003, 42, 4773. (c) Zampella, G.; Greco, C.; Fantucci, P.; de Gioia, L. Inorg. Chem. 2006, 45, 4109. (d) Bruschi, M.; Greco, C.; Kaukonen, M.; Fantucci, P.; Ryde, U.; de Gioia, L. Angew. Chem., Int. Ed. 2009, 48, 3503. (e) Bruschi, M.; Greco, C.; Fantucci, P.; De Gioia, L. Inorg. Chem. 2008, 47, 6056. (f) Greco, C.; de Gioia, L. Inorg. Chem. 2011, 50, 6987. (g) Greco, C.; Bruschi, M.; Fantucci, P.; Ryde, U.; de Gioia, L. J. Am. Chem. Soc. 2011, 133, 18742. (h) Ryde, U.; Greco, C.; de Gioia, L. J. Am. Chem. Soc. 2010, 132, 4512.

(20) Siegbahn, P. E. M.; Tye, J. W.; Hall, M. B. Chem. Rev. 2007, 107, 4414.

(21) (a) Cao, Z.; Hall, M. B. J. Am. Chem. Soc. 2001, 123, 3734.

(b) Fan, H.-J.; Hall, M. B. J. Am. Chem. Soc. 2001, 123, 3828.

(c) Thomas, C. M.; Liu, T.; Hall, M. B.; Darensbourg, M. Y. Inorg. Chem. 2008, 47, 7009. (d) Thomas, C. M.; Liu, T.; Hall, M. B.; Darensbourg, M. Y. Chem. Commun. 2008, 1563-1565.

(22) Fiedler, A. T.; Brunold, T. C. Inorg. Chem. 2005, 44, 9322.

(23) (a) Liu, Z.-P.; Hu, P. J. Am. Chem. Soc. 2002, 124, 5175. (b) Liu, Z.-P.; Hu, P. J. Chem. Phys. 2002, 117, 8177.

(24) Stiebritz, M.; T.; Reiher, M. Inorg. Chem. 2009, 48, 7127.

(25) Noyori, R. Angew. Chem., Int. Ed. 2002, 41, 2008.

(26) Yamakawa, M.; Ito, H.; Noyori, R. J. Am. Chem. Soc. 2000, 122, 1466. 